\title{
TREK-TRAAK two-pore domain potassium channels protect human retinal pigment epithelium cells from oxidative stress
}

\author{
HAO HUANG, HAN LI, KANGPEI SHI, LEI WANG, XIAOTONG ZHANG and XIAOBO ZHU \\ State Key Laboratory of Ophthalmology, Zhongshan Ophthalmic Center, \\ Sun Yat-sen University, Guangzhou, Guangdong 510060, P.R. China
}

Received October 18, 2017; Accepted July 31, 2018

DOI: $10.3892 /$ ijmm.2018.3813

\begin{abstract}
The aim of the current study was to explore the potential of TREK-TRAAK two-pore domain potassium (K2P) channels in protecting human retinal pigment epithelium (hRPE) cells against oxidative stress. hRPE cells were obtained from donors, and then cell identification and detection of the expression levels of TREK-TRAAK K2P channels in hRPE cells were conducted. Subsequently, tert-butyl hydroperoxide (t-BH) was used to induce oxidative stress in hRPE cells. Docosahexaenoic acid (DHA) was used to stimulate and fluoxetine was used to inhibit the TREK-TRAAK K2P channels. The survival rates of hRPE cells under oxidative stress were examined using flow cytometry. Apoptosis-associated factors, including Bax, Bcl-2, cleaved-caspase-3, $\alpha \mathrm{B}$-crystallin and their mRNAs, were examined using immunofluorescence, western blot and reverse transcription-polymerase chain reaction analyses. Variations in the cytoarchitecture were observed by immunofluorescence and electron microscopy. The cells examined in the present study were identified as hRPE cells. All members in the TREK-TRAAK K2P channel family (including TREK-1, TREK-2 and TRAAK) were found to be expressed in hRPE cells. Stimulation of TREK-TRAAK $\mathrm{K} 2 \mathrm{P}$ channels increased the survival rates of hRPE cells under oxidative stress and the levels of intracellular protective factors, such as Bcl-2 and $\alpha \mathrm{B}$-crystallin. By contrast, inhibition of these channels decreased the cell survival rates and increased apoptosis enhancing factors, such as Bax and cleaved-caspase-3. Further examination of the cytoarchitecture revealed that TREK-TRAAK K2P channels protected the integrity of the hRPE cell structure against oxidative stress. In conclusion, the present study suggested that the activated
\end{abstract}

Correspondence to: Dr Xiaobo Zhu, State Key Laboratory of Ophthalmology, Zhongshan Ophthalmic Center, Sun Yat-sen University, 54 Xianlie Road South, Guangzhou, Guangdong 510060, P.R. China

E-mail: zhuxbo@mail.sysu.edu.cn

Key words: TREK-TRAAK, two-pore domain potassium channels, human retinal pigment epithelium cells, oxidative stress, retinal degeneration, apoptosis
TREK-TRAAK K2P channels serve a role in protecting hRPE cells against the oxidative stress induced by $\mathrm{t}-\mathrm{BH}$, which indicated that these $\mathrm{K} 2 \mathrm{P}$ channels are potential novel targets in retinal protection and provided a new direction for research and therapy in retinal degeneration diseases.

\section{Introduction}

Retinal degeneration diseases, such as age-related macular degeneration (AMD) and retinitis pigmentosa (RP), threaten the health and quality of life in humans (1). Retinal pigment epithelium (RPE) cells are involved in these diseases (2). The majority of pathways contributing to cell death share a common ultimate pathway, namely the regulation of caspase signaling. However, the existing inhibitors of this pathway display no capability of completely stopping the apoptotic process, indicating that the identification of efficient upstream targets that regulate apoptosis is necessary $(3,4)$.

Weakly inward rectifying potassium channels, including TREK and TRAAK, are members of the two-pore domain potassium (K2P) channels and are mainly found in the central nervous system (CNS). They contribute to the background (leak) potassium currents and regulate the viability of cells $(5,6)$. Previous studies have focused on the functions and mechanism of the channels, such as their roles in CNS degenerative disease processes, synaptic transmission, the maintenance of membrane resting potential and cell volume regulation (7-9). In degenerative processes of ischemia-induced neurons, the TRAAK channels demonstrate the ability to downregulate neuronal excitability that leads to lower cellular metabolic rate (10-12).

The retina, as a direct extension of the CNS, possesses physiological structures and functions resembling those of the encephalon. Its degeneration mechanism and performance have several properties that are similar to those in the CNS. Thus, it is hypothesized that the TRAAK K2P would also be involved in the inhibition of retinal cell apoptosis. The activity of these channels is regulated by mechanical stretch, polyunsaturated fatty acids (PUFAs), different drugs, extracellular $\mathrm{pH}$ and osmotic pressure among others (13). Docosahexaenoic acid (DHA) is one of the PUFAs that has been reported to be an activator of these channels and important in maintaining the integrity of RPE cells and photoreceptors (14). Several pharmacological agents, such as fluoxetine, inhibit the activity 
of these channels. Fluoxetine has also been reported to strongly suppress the PUFA-mediated currents of TREK-TRAAK K2P channels (15-17). Therefore, the present study investigated the underlying mechanism of these channels using DHA as a stimulator, while utilizing fluoxetine as an inhibitor.

In our previous studies, it was observed that riluzole (also known as 2-amino-6-trifluoromethoxy benzothiazole), a neuroprotective drug and activator of TRAAK channels, exhibited the ability to protect human RPE (hRPE) cells against oxidative injury-induced cell death (18) through stabilizing the mitochondrial membrane potential and preventing the release of cytochrome $c$ (19). In order to better evaluate the effects of the these channels against apoptosis, the present study used DHA to stimulate this channel, while utilizing fluoxetine as a TREK-TRAAK K2P inhibitor.

\section{Materials and methods}

Cell extraction and identification. The present study was conducted in accordance with the Declaration of Helsinki and approved by the Medical Ethics Committee of Zhongshan Ophthalmic Center, Sun Yat-sen University (Guangzhou, China). Written informed consent was obtained for all study participants. A total of 8 bulbus oculi were obtained from 5 adult donors, all of whom succumbed following traffic collisions (median age, 26; age range 19-40; 3 males, 2 females; collected between January 2014 and October 2015). HRPE cells were extracted from 8 eyecups of these bulbus oculi subsequent to the application of corneal transplantation, performed at the State Key Laboratory of Ophthalmology (Guangzhou, China). The cell culture, storage and subculture were performed following previously described guidelines (20). Subsequent experiments were performed on the fourth generation of hRPE cells, when the cells had reached the optimum level of cell viability and morphology, in which the cell confluence rate reached between 70 and $90 \%$. Cell identification was conducted using immunofluorescent staining of RPE-specific $65 \mathrm{kDa}$ protein (RPE65) and pan Cytokeratin antibodies as described below.

Cell culture and subgroups. The hRPE cells were divided into following groups: Control group, model group, channel-activated group and channel-inhibited group. Cells were first cultured in medium comprising 90\% DMEM/F12 (Gibco; Thermo Fisher Scientific, Inc., Waltham, MA, USA) and $10 \%$ fetal bovine serum (Sijiqing, Zhejiang Tianhang Biotechnology Co., Ltd.; Hangzhou, Zhejiang, China), at $25^{\circ} \mathrm{C}$. In the model group (t-BH group), the medium was removed and replaced with medium containing $300 \mu \mathrm{mol} / 1$ t-BH (Sigma-Aldrich; Merck KGaA, Darmstadt, Germany) for 3 and $6 \mathrm{~h}$ in order to achieve the desired cell death. In the channel-activated group, $10 \mu \mathrm{mol} / 1$ DHA (Sigma-Aldrich; Merck KGaA) was used to stimulate the TREK-TRAAK K2P channels. Briefly, hRPE cells were pre-cultured in medium containing $10 \mu \mathrm{mol} / 1 \mathrm{DHA}$ for $24 \mathrm{~h}$ before the replacement of medium containing $300 \mu \mathrm{mol} / 1 \mathrm{t}-\mathrm{BH}$. In the channel-inhibited group, fluoxetine (Sigma-Aldrich; Merck KGaA) was used to block the TREK-TRAAK K2P channels by adding into the medium together with $10 \mu \mathrm{mol} / 1 \mathrm{DHA}$. Briefly, in this group, hRPE cells were co-cultured in medium containing $10 \mu \mathrm{mol} / 1$ DHA and $70 \mu \mathrm{mol} / 1$ fluoxetine for $24 \mathrm{~h}$ before inducing oxidative stress by culturing the cells in medium containing $300 \mu \mathrm{mol} / 1 \mathrm{t}-\mathrm{BH}$ in the model group, channel-activated group and channel-inhibited group.

Flow cytometry. The survival rate of hRPE cells was tested using the flow cytometry technique with an Annexin V/PI apoptosis detection kit (BD Biosciences, Franklin Lakes, NJ, USA). The experiment was conducted in accordance with the protocol described in the kit. The cell quantity of each sample was adjusted to $10^{5}$ cells $/ \mathrm{ml}$ prior to testing.

Immunofluorescence assay. The expression levels of TREKTRAAK channel proteins in hRPE cells were tested by immunofluorescence assay. The variations in apoptosis-associated factors were examined, with Bax and Bcl-2 levels measured in groups treated with t-BH for $3 \mathrm{~h}$, and cleaved-caspase- 3 and $\alpha \mathrm{B}$-crystallin levels tested in groups treated with $\mathrm{t}-\mathrm{BH}$ for 3 and $6 \mathrm{~h}$. In addition, F-actin and $\alpha$-Tubulin levels were measured to observe the variations in the cytoskeleton in groups treated with t-BH for 3 and $6 \mathrm{~h}$.

Briefly, the cells were fixed with $4 \%$ paraformaldehyde for 15 min under $4^{\circ} \mathrm{C}$, permeabilized with $0.1 \%$ Triton X-100-PBS for $5 \mathrm{~min}$, and blocked in goat serum for $1 \mathrm{~h}$ at $25^{\circ} \mathrm{C}$. Next, the cells were subjected to overnight incubation with the primary antibody at $4^{\circ} \mathrm{C}$. After washing three times in PBS, the cells were incubated with secondary antibodies for another $30 \mathrm{~min}$ at $25^{\circ} \mathrm{C}$ in the dark. Subsequent to washing in PBS, cell nuclei were separately counterstained with RedDot1 (Biotium, Fremont, CA, USA) for cell identification or with Hoechst 33342 (Beyotime Institute of Biotechnology, Haimen, China) for immunofluorescence within $10 \mathrm{~min}$. Detection was then performed using a fluorescence microscope (BX53; Olympus Corporation, Tokyo, Japan), and the images were analyzed with image-pro plus 6.0 (Media Cybernetics, Rockville, MD, USA). The primary antibodies and secondary antibodies used were as follows: Mouse anti-RPE65 (1:200; cat. ab13826; Abcam, Cambridge, MA, USA), mouse anti-pan Cytokeratin (1:200; cat. SAB5300264; Sigma-Aldrich; Merck KGaA), rabbit anti-TREK-1 (1:400; cat. sc-50412), rabbit anti-TREK-2 (1:400; cat. sc-98688), rabbit anti-TRAAK (1:400; cat. sc-50413) (both from Santa Cruz Biotechnology, Inc., Dallas, TX, USA), mouse anti-Bax (1:400; cat. ab77566), rabbit anti-Bcl-2 (1:400; cat. ab32124) (both from Abcam), rabbit anti-cleaved-caspase-3 (1:400; cat. SAB1305630), rabbit anti- $\alpha$ B-crystallin (1:400; cat. SAB4500486) (both from Sigma-Aldrich; Merck KGaA), goat anti-mouse Alexa Fluor 488-conjugated IgG $(\mathrm{H}+\mathrm{L}), \mathrm{F}(\mathrm{ab}) 2$ Fragment (1:500; cat. \#4408; Cell Signaling Technology, Inc., Danvers, MA, USA) and goat anti-rabbit Alexa Fluor 555-conjugated IgG $(\mathrm{H}+\mathrm{L}), \mathrm{F}\left(\mathrm{ab}^{\prime}\right) 2$ Fragment (1:500; cat. \#4413; Cell Signaling Technology, Inc.). Immunofluorescence examinations of different groups were performed under consistent condition.

Western blot analysis. Variations in the levels of apoptosis-associated factors, including Bax, Bcl-2, cleaved-caspase-3 and $\alpha \mathrm{B}$-crystallin, were assessed by western blot assay in groups treated with t-BH for 3 and $6 \mathrm{~h}$. Briefly, hRPE cells in the different groups were washed three times with ice-cold PBS and lysed in radioimmunoprecipitation assay buffer (Beyotime Institute of Biotechnology). The lysates were then 
centrifuged for $10 \mathrm{~min}$ under $12,000 \mathrm{xg}$ at $4^{\circ} \mathrm{C}$, followed by electrophoresis at $75 \mathrm{~V}$ in $15 \%$ SDS-PAGE separation gel, then the proteins were electrotransferred at $300 \mathrm{~mA}$ for $30 \mathrm{~min}$ to polyvinylidene difluoride membranes with a $0.2 \mu \mathrm{m}$ pore size (cat. 88520; Invitrogen; Thermo Fisher Scientific, Inc.). The membranes were subsequently blocked using $5 \%$ bovine serum albumin (Sigma-Aldrich; Merck KGaA) at $25^{\circ} \mathrm{C}$ for $1 \mathrm{~h}$. Following incubation overnight with the primary antibody solutions under $4^{\circ} \mathrm{C}$, the membranes were washed three times in PBS and then incubated with the secondary antibodies for another $30 \mathrm{~min}$ at $25^{\circ} \mathrm{C}$. Detection was then performed using Pierce ${ }^{\mathrm{TM}}$ ECL western blotting substrate (cat. 32106; Invitrogen; Thermo Fisher Scientific, Inc.) and analyzed with image-pro plus (version 6.0; Media Cybernetics; MD, USA). The primary and secondary antibodies used in this assay were the following: Mouse anti-Bax (1:1,000; cat. ab77566; Abcam), rabbit anti-Bcl-2 (1:1,000; cat. ab32124; Abcam), rabbit anti-cleaved-caspase-3 (1:1,000; cat. SAB1305630; Sigma-Aldrich; Merck KGaA), rabbit anti- $\alpha \mathrm{B}$-crystallin (1:1,000; cat. SAB4500486; Sigma-Aldrich; Merck KGaA), horse anti-mouse horseradish peroxidase (HRP)-conjugated IgG (1:3,000; cat. \#7076; Cell Signaling Technology, Inc.) and goat anti-rabbit HRP-conjugated IgG (1:3,000; cat. \#7074; Cell Signaling Technology, Inc.).

Reverse transcription-polymerase chain reaction (RT-PCR). RT-PCR analysis was performed to detect early variations in the Bax, Bcl-2, caspase- 3 and $\alpha \mathrm{B}$-crystallin mRNA levels only in groups treated with t-BH for $3 \mathrm{~h}$. Briefly, cells in different groups were washed three times with ice-cold PBS, lysed in TRIzol reagent buffer (Invitrogen; Thermo Fisher Scientific, Inc.) and then centrifuged for 8 min under $13,000 \mathrm{x}$ g at $4^{\circ} \mathrm{C}$. RNA concentration was measured using a nano drop (Thermo Fisher Scientific, Inc.). Total RNA was reverse transcribed using the RevertAid First Strand cDNA Synthesis kit (Thermo Fisher Scientific, Inc.), and then FastStart Universal SYBR Green Master (Roche Diagnostics GmbH, Mannheim, Germany) and specific primers were used for the PCR process. The thermocycling conditions were as follows: Stage $1,42^{\circ} \mathrm{C}$ for $5 \mathrm{~min}, 95^{\circ} \mathrm{C}$ for $10 \mathrm{sec}$ for $1 \mathrm{cycle}$; stage $2,95^{\circ} \mathrm{C}$ for $5 \mathrm{sec}, 60^{\circ} \mathrm{C}$ for $30 \mathrm{sec}$ for 40 cycles; stage 3 (dissociation protocol), $95^{\circ} \mathrm{C}$ for $1 \mathrm{sec}$, $65^{\circ} \mathrm{C}$ for $15 \mathrm{sec}$. Results were quantified using a StepOnePlus Real-Time PCR System (Thermo Fisher Scientific, Inc.). The quantification cycle (Cq) number was set by the StepOne Software (version 2.3; Thermo Fisher Scientific, Inc.). The expression levels of the tested mRNA were presented as the Cq compared with the $\beta$-actin mRNA in each sample (21). The primer sequences were as follows: $\beta$-actin, forward, CACCC AGCACAATGAAGATCAAGAT and reverse, CAGTTTTTA AATCCTGAGTCAAGC; caspase3, forward, TGGAAGCGA ATCAATGGACTCT and reverse, TGAATGTTTCCCTGA GGTTTGC; $\alpha \mathrm{B}$-crystallin, forward, CGCCTCTTTGACCAG TTCTTC and reverse, CTCAATCACATCTCCCAACACCT; bax, forward, TTTTGCTTCAGGGTTTCATCCA and reverse, TGCCACTCGGAAAAAGACCTC; bcl2, forward, ATCGCC CTGTGGATGACTGA and reverse, GAGACAGCCAGGAGA AATCAAAC.

Electron microscopy. Late-stage variations in the cytoarchitecture were observed by scanning electron microscopy (SEM) and transmission electron microscopy (TEM) in groups which treated with t-BH for $6 \mathrm{~h}$. Briefly, cells were fixed with $2.5 \%$ pentanediol and $4 \%$ paraformaldehyde for $24 \mathrm{~h}$ at $4{ }^{\circ} \mathrm{C}$, subjected to four-step dehydration with ethanol at 10, 30,70 and $99 \%$ for 30 min each at room temperature, then coated with silver using Leica EM Sample Preparation (Genmany) for SEM and embedded with epoxy resin (cat. GMS11012; Genmed, Shanghai, China) for TEM. Observation of the cell samples by SEM and TEM was then performed.

Statistical analysis. Data are expressed as the mean \pm standard deviation. Differences between groups were assessed with one-way analysis of variance. Statistical analysis was conducted with SPSS statistical software (version 13.0; SPSS, Inc., Chicago, IL, USA). A value of $\mathrm{P}<0.05$ was considered as indicative of a statistical significance difference.

\section{Results}

TREK-TRAAK K2P channels are expressed in hRPE cells. TREK-TRAAK K2P channels have been reported to be predominantly expressed in the human CNS (13); however, they have not been studied in hRPE cells. In the present study, the extracted cells were identified to be hRPE cells via immunofluorescence (Figs. 1 and 2). Furthermore, expression of all three members of the TREK-TRAAK K2P channel family, including TREK-1, TREK-2 and TRAAK, was observed in the hRPE cells, with diffused distribution detected across the surface of hRPE cells (Fig. 3), and the spatial expression and quantity of the three members' protein exhibited no difference.

TREK-TRAAK K2P channels protect hRPE cells from oxidative stress. $\mathrm{t}-\mathrm{BH}$ induces oxidative stress in hRPE cells and causes cell death. In the current study, the TREK-TRAAK K2P channels in hRPE cells were stimulated using DHA, while this stimulation was blocked by co-treated with fluoxetine. Evaluation of the protective effects of the channels was conducted using Annexin V/PI staining and flow cytometry (Fig. 4). Following exposure to $300 \mu \mathrm{mol} / \mathrm{l} \mathrm{t}-\mathrm{BH}$ for $3 \mathrm{~h}$, the survival rate of hRPE cells was significantly decreased from $98.7 \pm 0.2$ to $77.7 \pm 3.0 \%$. The use of DHA raised the survival rate to $89.8 \pm 0.6 \%$, while co-treatment with fluoxetine markedly reduced the survival rate to $65.4 \pm 2.6 \%$. Similar results were obtained when the exposure was prolonged to $6 \mathrm{~h}$. The survival rate of hRPE cells treated with $300 \mu \mathrm{mol} / \mathrm{l}$ t-BH for $6 \mathrm{~h}$ was significantly decreased to $50.8 \pm 3.0 \%$, while the survival rate was $82.8 \pm 1.5 \%$ in the group treated with DHA and $45.5 \pm 0.7 \%$ in the group co-treated with fluoxetine.

The variations in the survival rates indicated that the TREK-TRAAK K2P channels served a protective function against oxidation in hRPE cells. Stimulating the TREK-TRAAK K2P channels resulted in higher cell survival rates under oxidative stress, whereas blocking the channels led to lower survival rates of hRPE cells.

TREK-TRAAK K2P channels regulate several apoptosisassociated factors in hRPE cells. Using immunofluorescence (Figs. 5 and 6) and western blot analysis (Fig. 7), it was observed that 3-h treatment with $300 \mu \mathrm{mol} / \mathrm{l} \mathrm{t}-\mathrm{BH}$ greatly increased the amount of Bax in hRPE cells under oxidative stress, while 


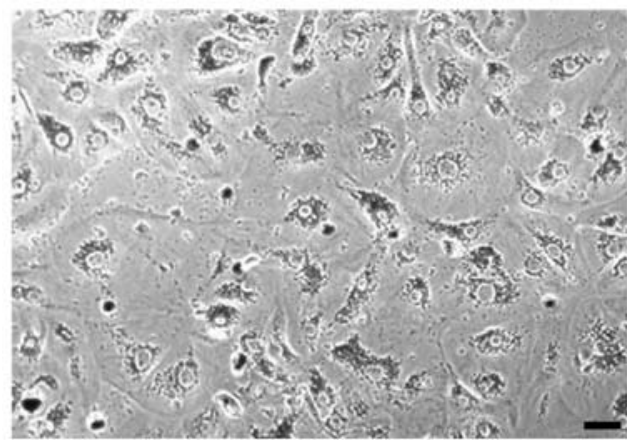

POhRPE cells

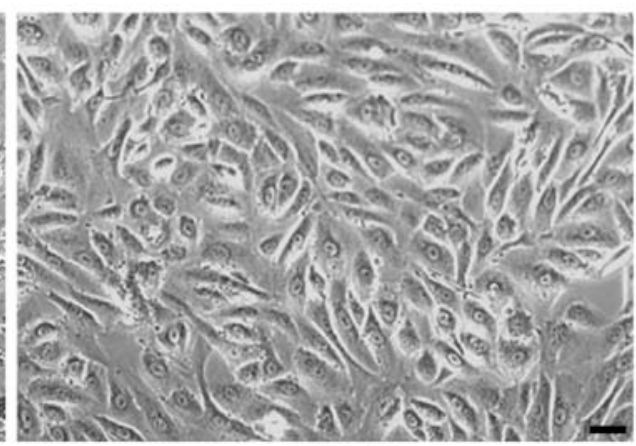

P4hRPE cells

Figure 1. Cultured hPRE cells. Primary (P0) hRPE cells were big irregularly shaped cells containing a great amount of pigment granules. With the progression of the cell passage, hRPE cells became smaller fusiform cells with less pigment granules. Cell viability reached a peak value in the fourth generation (P4) of hRPE cells, at which regularly shaped cells of similar size were observed (scale bar, $20 \mu \mathrm{m}$ ). hRPE, human retinal pigment epithelium.
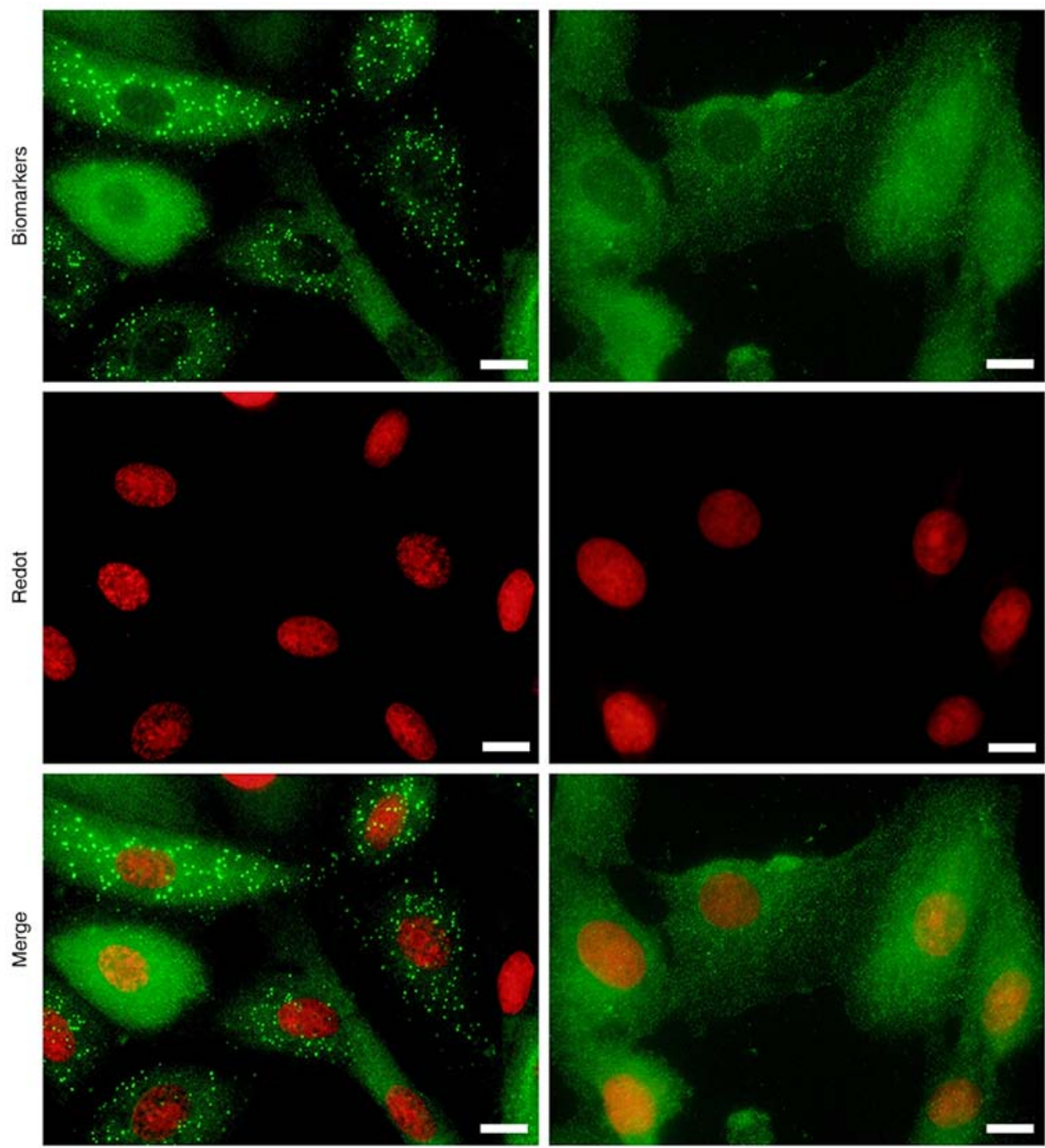

RPE65

pan Cytokeratin

Figure 2. Cell identification. RPE65 and pan Cytokeratin were labeled with Alexa Fluor 488-conjucated antibodies (green), and nuclei were labeled with RedDot1 (red). Sand-like distribution of RPE65 was observed, while diffuse distribution of pan Cytokeratin was detected (scale bar, $10 \mu \mathrm{m})$. RPE65, retinal pigment epithelium-specific $65 \mathrm{kDa}$ protein.

Bcl-2 expression was decreased. Introduction of $10 \mu \mathrm{mol} / 1$ DHA for $24 \mathrm{~h}$ prior to $\mathrm{t}-\mathrm{BH}$ exposure inhibited the variation in these factors, reducing the increase in Bax and the decrease in Bcl-2 expression. However, co-treatment with $70 \mu \mathrm{mol} / 1$ fluoxetine for $24 \mathrm{~h}$ alongside DHA reversed this inhibition. Similar changes were identified for cleaved-caspase-3 expression. Following treatment with $300 \mu \mathrm{mol} / \mathrm{l} \mathrm{t}-\mathrm{BH}$ for 3 and $6 \mathrm{~h}$, the levels of cleaved-caspase-3 were significantly enhanced. 

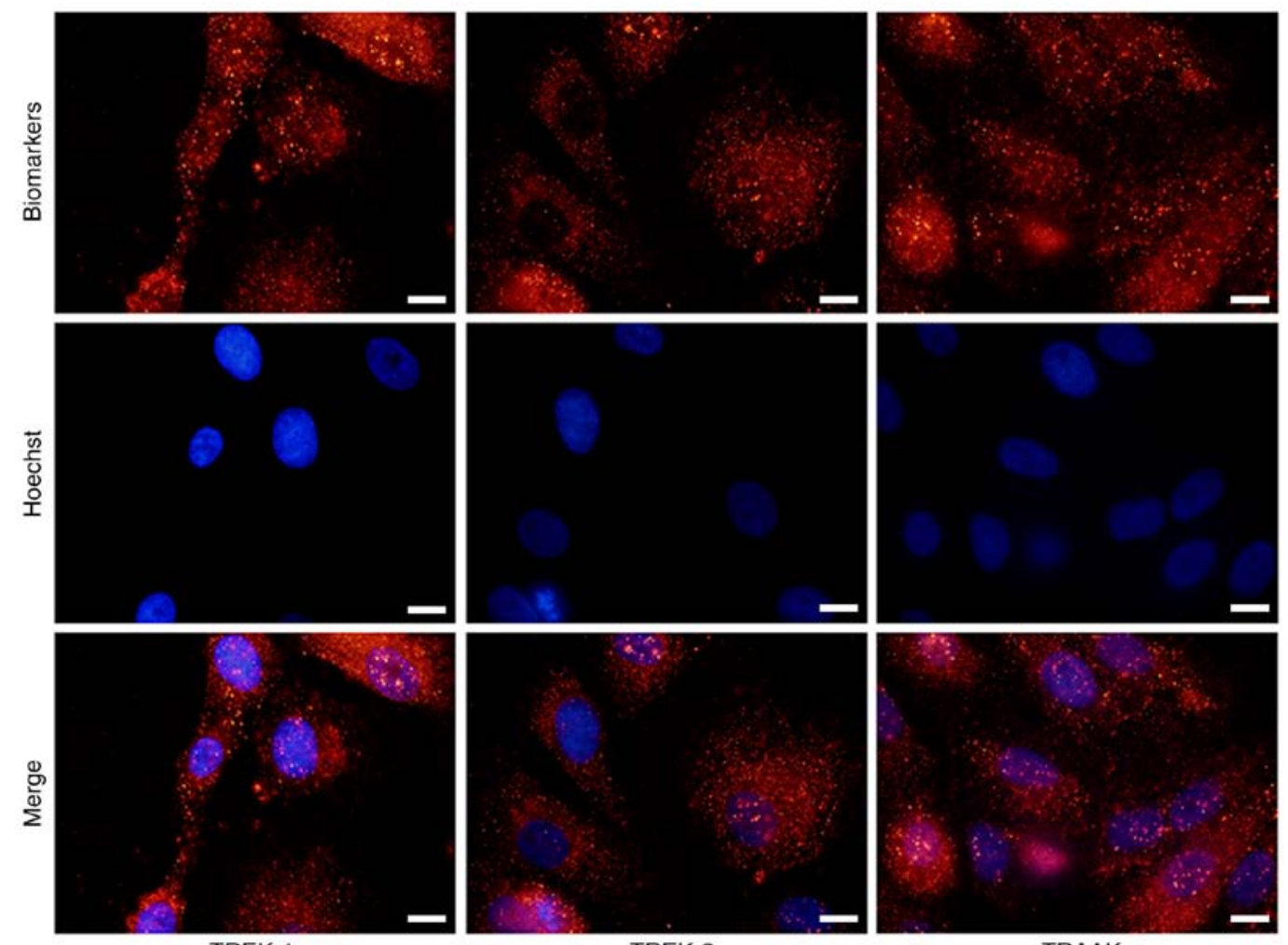

TREK-2

TRAAK

Figure 3. Expression of TREK-TRAAK K2P channel family members (TREK-1, TREK-2 and TRAAK) in human retinal pigment epithelium cells. TREK-TRAAK K2P channels were labeled with Alexa Fluor 555-conjugated antibodies (red), and nuclei were labeled with Hoechst 33342 (blue). Sand-like distribution of channels was observed (scale bar, $10 \mu \mathrm{m}$ ). K2P, two-pore domain potassium.

DHA was found to restrain the change in cleaved-caspase-3, while fluoxetine was able to neutralize the function of DHA. Regarding $\alpha \mathrm{B}$-crystallin expression, the variations were slightly different (Figs. 6 and 7). Oxidative stress raised the levels of $\alpha \mathrm{B}$-crystallin after 3-h treatment with $300 \mu \mathrm{mol} / \mathrm{l}$ $\mathrm{t}-\mathrm{BH}$, while it caused $\alpha \mathrm{B}$-crystallin reduction in the $6-\mathrm{h}$ group. Furthermore, pretreatment with DHA increased the $\alpha \mathrm{B}$-crystallin levels, whereas fluoxetine depressed the amount of $\alpha \mathrm{B}$-crystallin.

Using RT-PCR (Fig. 8), the early variations in Bax, Bcl-2, caspase-3 and $\alpha \mathrm{B}$-crystallin mRNA levels were observed in the group treated with $300 \mu \mathrm{mol} / \mathrm{l} \mathrm{t}-\mathrm{BH}$ for $3 \mathrm{~h}$. Since the quantity of mRNA is altered prior to the change in protein levels, treatment for $3 \mathrm{~h}$ served as an observational point. Consistently, the transcription levels of Bax and caspase-3 were enhanced after treatment with $\mathrm{t}-\mathrm{BH}$, while that of $\mathrm{Bcl}-2$ was decreased and a moderate rise was observed in $\alpha \mathrm{B}$-crystallin level. DHA was found to inhibit the transcription levels of Bax and caspase-3, and to promote $\mathrm{Bcl}-2$ and $\alpha \mathrm{B}$-crystallin. By contrast, fluoxetine treatment blocked the effect of DHA in this experiment. However, Bax in the group co-treated with fluoxetine was lower than expected, which may have resulted from severe oxidation inducing transcriptional function damage.

TREK-TRAAK K2P channels maintain the stabilization of the cytoarchitecture in hRPE cells. Immunofluorescence was used to detect the transformations of the cytoskeleton in hRPE cells under oxidative stress (Fig. 9). Following treatment with $300 \mu \mathrm{mol} / 1 \mathrm{t}-\mathrm{BH}$ for $3 \mathrm{~h}, \mathrm{~F}$-actin and $\alpha$-Tubulin were initially depolymerized, and partially dissolved. However, in the DHA group, transformation was not detected. In the fluoxetine co-treatment group, F-actin and $\alpha$-Tubulin were further disintegrated. In the group treated with $300 \mu \mathrm{mol} / \mathrm{l} \mathrm{t}-\mathrm{BH}$ for $6 \mathrm{~h}$, the natural framework of the cytoskeleton was hardly detected. However, DHA pretreatment helped maintain the majority of the normal cell structure, though the framework was nebulous in certain parts. By contrast, the cytoskeleton of cells in the fluoxetine group was worse compared with that in the t-BH group. Furthermore, immunofluorescence assay identified that the nuclei of hRPE cells in the t-BH group exhibited atrophy and apoptotic bodies appeared. In the DHA group, the atrophy was alleviated and apoptotic bodies were rarely observed, while deterioration of these features was observed in cells co-treated with fluoxetine (Fig. 9).

SEM was applied to examine the extracellular variations of the cytoarchitecture (Fig. 10). Treatment with $300 \mu \mathrm{mol} / 1$ $\mathrm{t}-\mathrm{BH}$ for $6 \mathrm{~h}$ led to atrophy and permeabilization of the cell membrane. Compared with the control, microvilli and pseudopodia of the $\mathrm{t}-\mathrm{BH}$ group had mostly vanished, while the cells turned spherical and began to abscise. By contrast, the cytoarchitecture of hRPE cells in the DHA group was close to normal. In the fluoxetine co-treatment group, the majority of hRPE cells collapsed as expected.

TEM was applied to examine the intracellular structural changes (Fig. 11). Subsequent to treatment of hRPE cells with $300 \mu \mathrm{mol} / \mathrm{l} \mathrm{t}-\mathrm{BH}$ for $6 \mathrm{~h}$, the majority of the normal intracellular structure had disappeared, and the following features were observed: Chromatin condensated, apoptotic bodies formed, cytoplasm dyeing decreased, mitochondrial edema emerged, and endoplasmic reticulum and Golgi bodies were destroyed. 

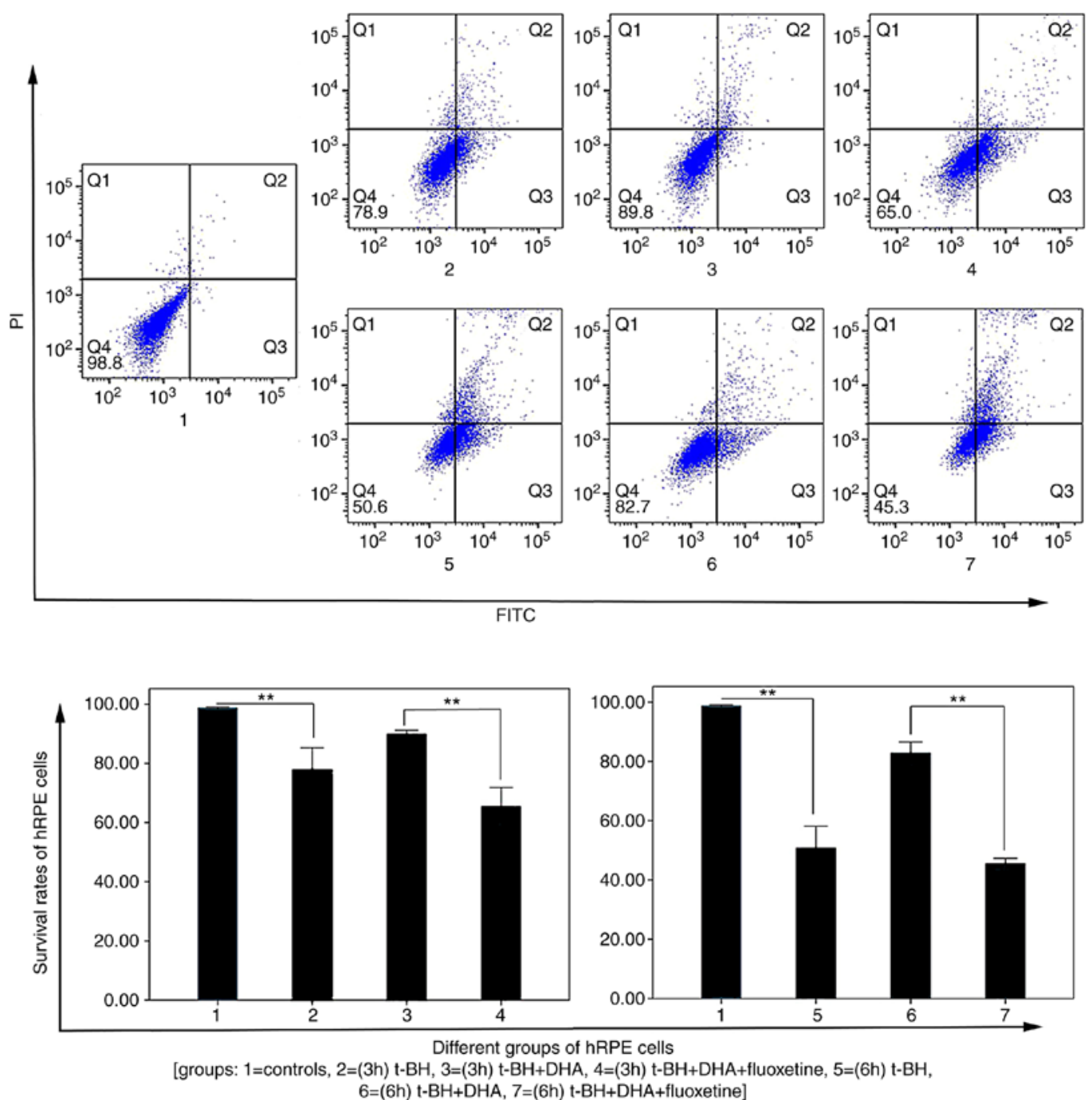

Figure 4. Survival rates of hRPE cells under oxidative stress. [Groups: $1=$ control, $2=(3 \mathrm{~h}) \mathrm{t}-\mathrm{BH}, 3=(3 \mathrm{~h}) \mathrm{t}-\mathrm{BH}+\mathrm{DHA}, 4=(3 \mathrm{~h}) \mathrm{t}-\mathrm{BH}+\mathrm{DHA}+\mathrm{fluoxetine}, 5=(6 \mathrm{~h})$ $\mathrm{t}-\mathrm{BH}, 6=(6 \mathrm{~h}) \mathrm{t}-\mathrm{BH}+\mathrm{DHA}, 7=(6 \mathrm{~h}) \mathrm{t}-\mathrm{BH}+\mathrm{DHA}+$ fluoxetine]. In the flow cytometry plots, the Q4 shows normal hRPE cells, Q3 shows cells at the early apoptosis stage, and Q2 shows cells at the late apoptosis stage. Differences between the control and t-BH groups, the t-BH and DHA groups, and the DHA and fluoxetine co-treatment groups were significant. Data are presented as the mean \pm standard error $(n=3)$ of experiments performed in triplicate. ${ }^{* *} \mathrm{P}<0.01$. $\mathrm{hRPE}$, human retinal pigment epithelium; t-BH, tert-butyl hydroperoxide; DHA, docosahexaenoic acid; Q, quadrant.

Pretreatment with $10 \mu \mathrm{mol} / \mathrm{l}$ DHA markedly reduced this collapse, although deformation of nuclei and cytoplasmic organoids were still identified. However, co-treatment with $70 \mu \mathrm{mol} / \mathrm{l}$ fluoxetine resulted in severe damage of the intracellular cytoarchitecture.

Taken together, stimulation of TREK-TRAAK K2P channels using DHA exhibited protective effects on hRPE cells under oxidative stress, while blocking the channels using fluoxetine affected the balance of the cytoarchitectural stability. As a result, TREK-TRAAK K2P channels appeared to have a protective role by maintaining the stabilization of the cytoarchitecture in hRPE cells under oxidative stress.

\section{Discussion}

The RPE is constituted by a simple layer of cuboidal cells, which is situated under the photoreceptors. It absorbs the majority of light energy and functions as a recycler of photoreceptors disk membrane in the retina, and is the structure that is first injured in multiple retinal degeneration diseases (22). In order to identify a new direction of research and therapies in refractory retinal diseases, such as AMD and RP, the current study explored the protective effects of activated TREK-TRAAK K2P channels on hRPE cells.

In the present study, all members in the TREK-TRAAK $\mathrm{K} 2 \mathrm{P}$ channels family were found to be expressed in hRPE cells (Fig. 3). These members were equally expressed with differences in spatial distribution or quantity. Although the specific function of each member of these channels should be further studied in the future, this is not considered to affect the findings of the present study, which focused on the protective effects of all TREK-TRAAK K2P channels on hRPE cells against oxidative stress. Oxidative stress was induced in hRPE cells by exposure to t-BH, which leads to apoptosis accompanied by variations in the levels of apoptosis-associated factors and cytoarchitecture. The channels were activated in the current study, and it was observed that the survival rates of hRPE cells were increased.

$\mathrm{Bax}, \mathrm{Bcl}-2$, cleaved-caspase- 3 and $\alpha \mathrm{B}$-crystallin are factors associated with cell apoptosis. The caspase-dependent 

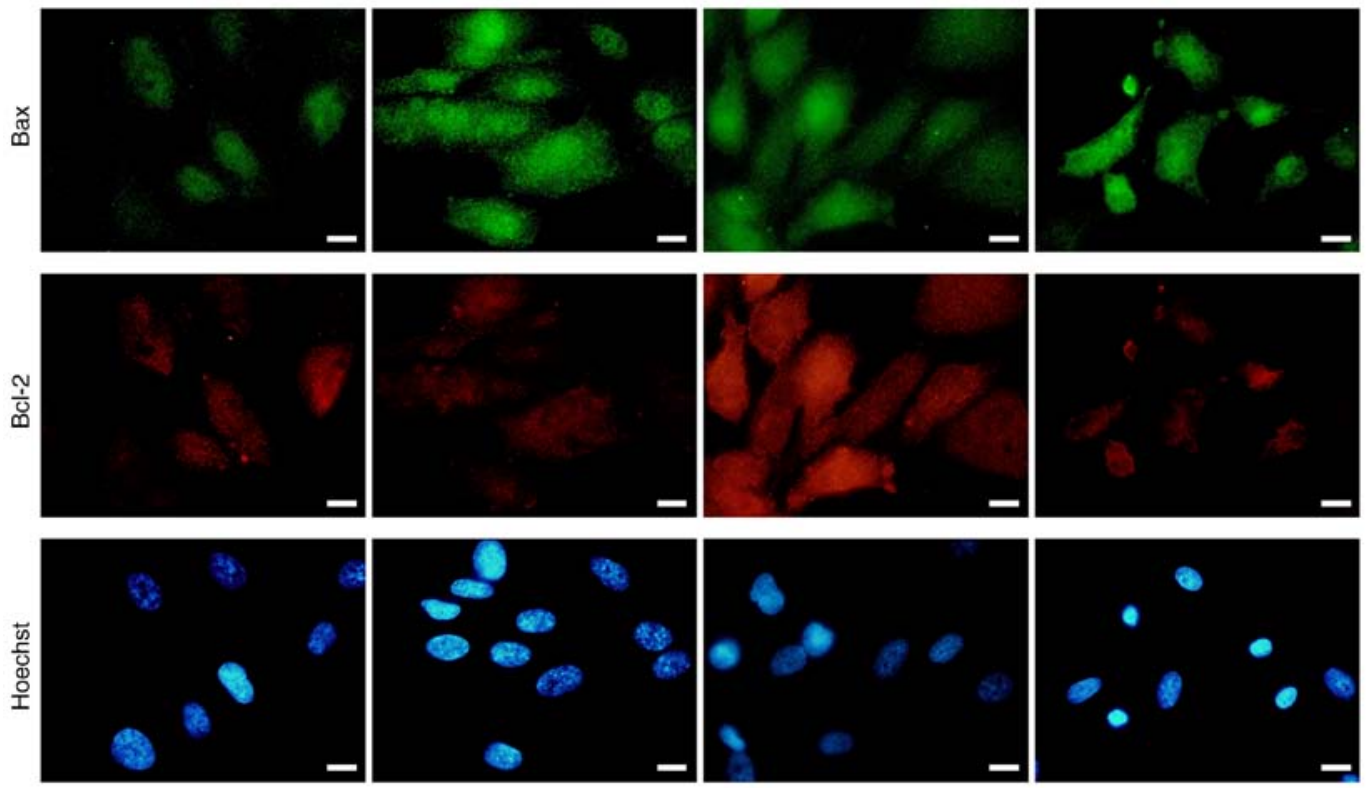

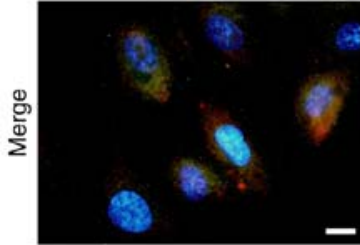

Controls

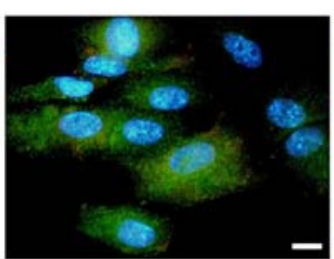

(3h) $\mathrm{t}-\mathrm{BH}$

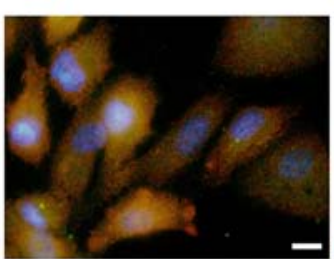

(3h) t-BH+DHA

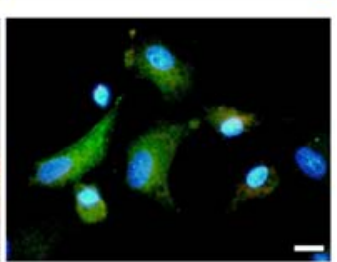

(3h) t-BH+DHA+fluoxetine

Figure 5. Immunofluorescence analysis revealed the variations in Bax and Bcl-2 expression. Treatment with $300 \mu$ mol/l $\mathrm{t}$ - $\mathrm{BH}$ for $3 \mathrm{~h}$ evidently increased Bax and decreased $\mathrm{Bcl}-2$ in human retinal pigment epithelium cells under oxidative stress. Introduction of $10 \mu \mathrm{mol} / 1 \mathrm{DHA}$ for $24 \mathrm{~h}$ before $\mathrm{t}-\mathrm{BH}$ exposure restrained these variations. However, co-treatment with $70 \mu \mathrm{mol} / 1$ fluoxetine for $24 \mathrm{~h}$ alongside DHA reversed the effects caused by DHA (scale bar, $10 \mu \mathrm{m}$ ). t-BH, tert-butyl hydroperoxide; DHA, docosahexaenoic acid.

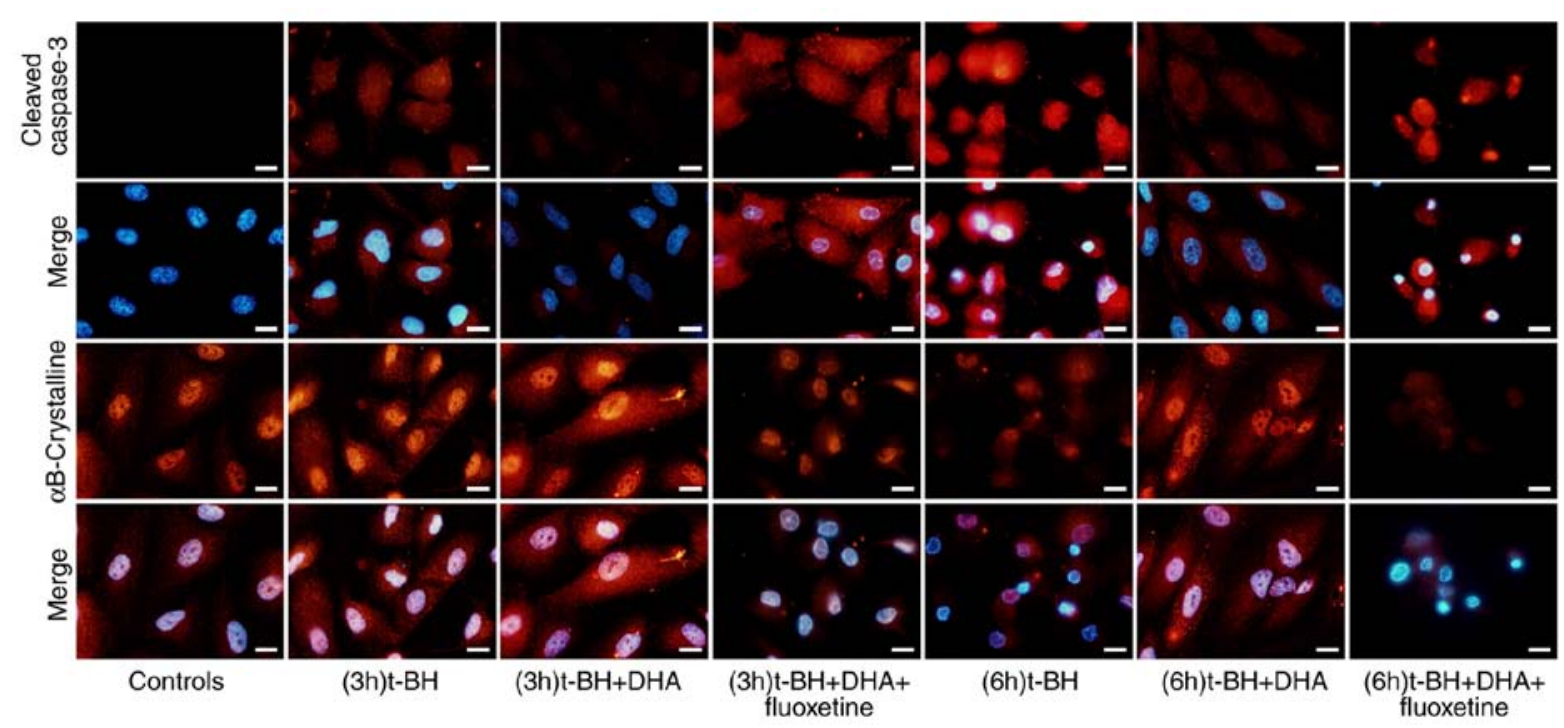

Figure 6. Immunofluorescence analysis revealed the variations in cleaved-caspase- 3 and $\alpha \mathrm{B}$-crystallin expression. Following treatment with $300 \mu$ mol/1 t-BH for 3 and $6 \mathrm{~h}$, the levels of cleaved-caspase- 3 were significantly enhanced. DHA was found to restrain this change, whereas fluoxetine was able to neutralize the function of DHA. Variations were slightly different for $\alpha \mathrm{B}$-crystallin: Oxidative stress raised the levels of $\alpha \mathrm{B}$-crystallin after 3-h treatment with 300 $\mu$ mol/1 t-BH, while causing $\alpha \mathrm{B}$-crystallin reduction in the 6-h group. Furthermore, pretreatment with DHA increased the $\alpha \mathrm{B}$-crystallin levels, whereas fluoxetine depressed the expression of $\alpha \mathrm{B}$-crystallin (scale bar, $10 \mu \mathrm{m}$ ). t-BH, tert-butyl hydroperoxide; DHA, docosahexaenoic acid.

signaling pathway is one of the cell apoptosis pathways, in which multiple factors are involved. Bax and Bcl-2 are factors that affect the early signaling and regulate the downstream caspase pathway (23). In addition, cleaved-caspase-3 is the major factor that gates the apoptosis process (24), while it is reported that $\alpha \mathrm{B}$-crystallin functions as a trans-acting factor of cleaved-caspase- 3 and can inhibit the apoptosis in the treated hRPE cells $(25,26)$. In the present study, the levels of the apoptosis 

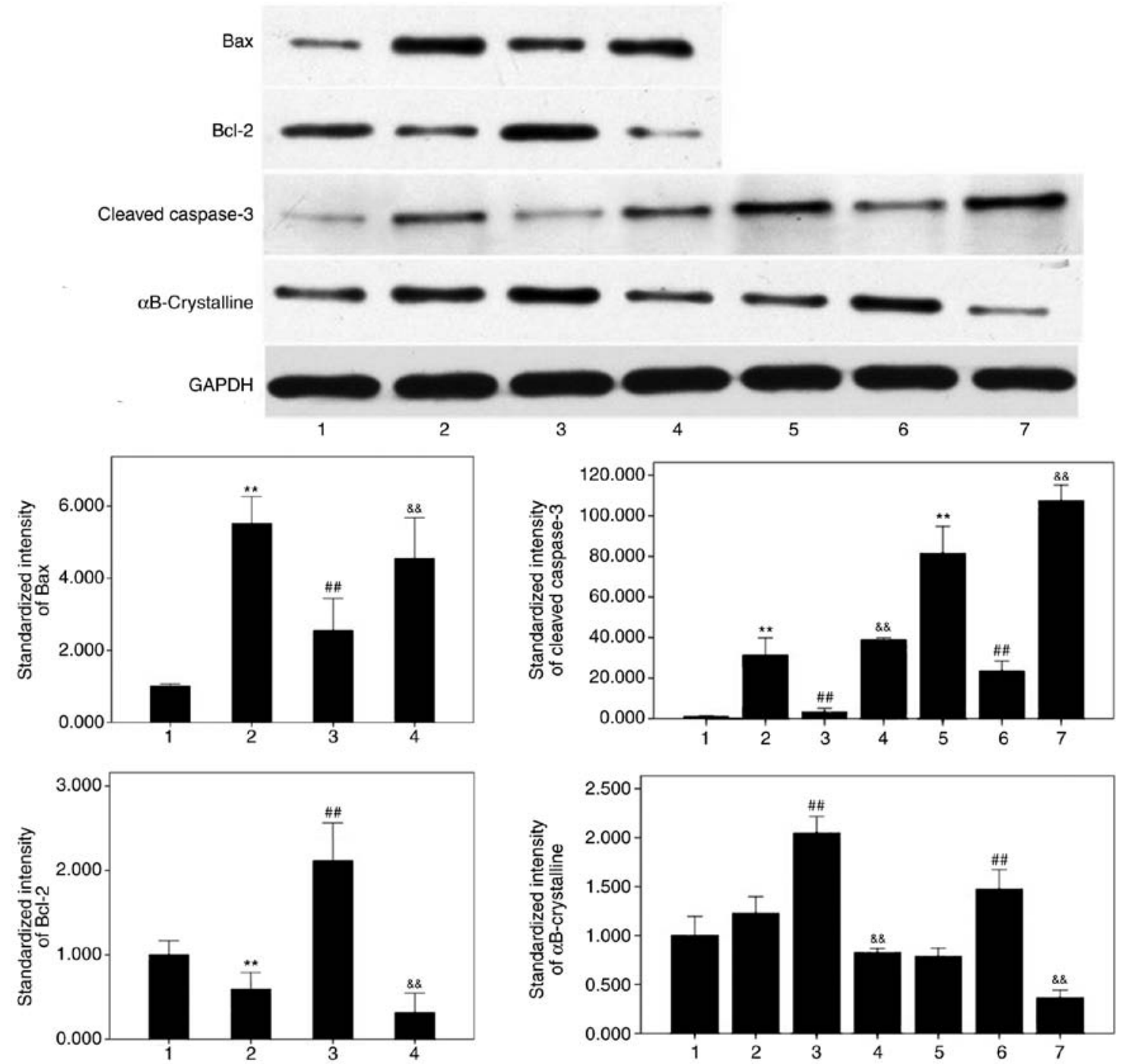

Figure 7. Western blot assay demonstrated the variations in Bax, Bcl-2, cleaved-caspase -3 and $\alpha \mathrm{B}$-crystallin expression levels. [Groups: $1=$ control, $2=(3 \mathrm{~h})$ $\mathrm{t}-\mathrm{BH}, 3=(3 \mathrm{~h}) \mathrm{t}-\mathrm{BH}+\mathrm{DHA}, 4=(3 \mathrm{~h}) \mathrm{t}-\mathrm{BH}+\mathrm{DHA}+$ fluoxetine, $5=(6 \mathrm{~h}) \mathrm{t}-\mathrm{BH}, 6=(6 \mathrm{~h}) \mathrm{t}-\mathrm{BH}+\mathrm{DHA}, 7=(6 \mathrm{~h}) \mathrm{t}-\mathrm{BH}+\mathrm{DHA}+\mathrm{fluoxetine}$. Following treatment with $300 \mu \mathrm{mol} / 1$, the levels of these factors were in accordance with the results of immunofluorescence assay. Data are presented as the mean \pm standard error $(\mathrm{n}=3)$, with experiments performed in triplicate. ${ }^{* *} \mathrm{P}<0.01$ vs. control group; ${ }^{\# /} \mathrm{P}<0.01$ vs. t-BH group; ${ }^{\&} \mathrm{P}<0.01$ vs. t-BH+DHA group.

promoting factors Bax and cleaved-caspase- 3 were reduced, while the levels of apoptosis restrainers Bcl-2 and $\alpha \mathrm{B}$-crystallin were enhanced in the t-BH+DHA group (Figs. 4-7). To confirm that the protective effect originated from the TREK-TRAAK K2P channels, an inhibitor of these channels was also applied, namely fluoxetine, which acted efficiently in reversing the protective effects of DHA (Figs. 4-7). However, Bax levels in the cell group co-treated with fluoxetine decreased, and this may be due to the continued oxidative stress destroying the Bax mRNA, which requires further investigation. Notably, the level of $\alpha \mathrm{B}$-crystallin was increased at the early stage of apoptosis, while it decreased at the late stage (Figs. 6 and 7). This may be due to $\alpha \mathrm{B}$-crystallin acting as a natural cellular protective factor in hRPE cells $(25,26)$. In the presence of oxidation, the self-protection system of cells induces the expressions of $\alpha \mathrm{B}$-crystallin; however, if the oxidation lasts for a sufficient amount of time to destroy the self-protection system, then expression level of $\alpha \mathrm{B}$-crystallin may fall. Consistent results were also observed for the mRNAs of Bax, Bcl-2, caspase-3 and $\alpha \mathrm{B}$-crystallin (Fig. 8). TREK-TRAAK K2P channels restrained the apoptotic process through decreasing the transcription of Bax and caspase- 3 and increasing that of Bcl-2 and $\alpha B$-crystallin. Taken together, these results indicated that the mechanism of the cellular protective effects of TREK-TRAAK $\mathrm{K} 2 \mathrm{P}$ channels are achieved by regulating apoptosis-associated factors.

Variations in the cytoarchitecture are also indicators of apoptosis (27). When the cytoarchitecture collapses, it is difficult to reverse the apoptosis. Therefore, the stabilization of hRPE cells suffering from oxidation was applied to observe the protective effects induced by TREK-TRAAK K2P channels. The cellular dynamics and morphology are linked to different molecular biological factors (including $\mathrm{F}$-actin and $\alpha$-Tubulin), as well as subcellular structures $(28,29)$. The condition of the nuclei, mitochondria, cytoplasm and cytoplasmic organoids varies along with the status of cellular homeostasis (30). In the current study, it was observed that stimulation of the TREK-TRAAK K2P channels resulted in stabilization of the cytoarchitecture. By contrast, inhibition of these channels was found to reverse this effect. 


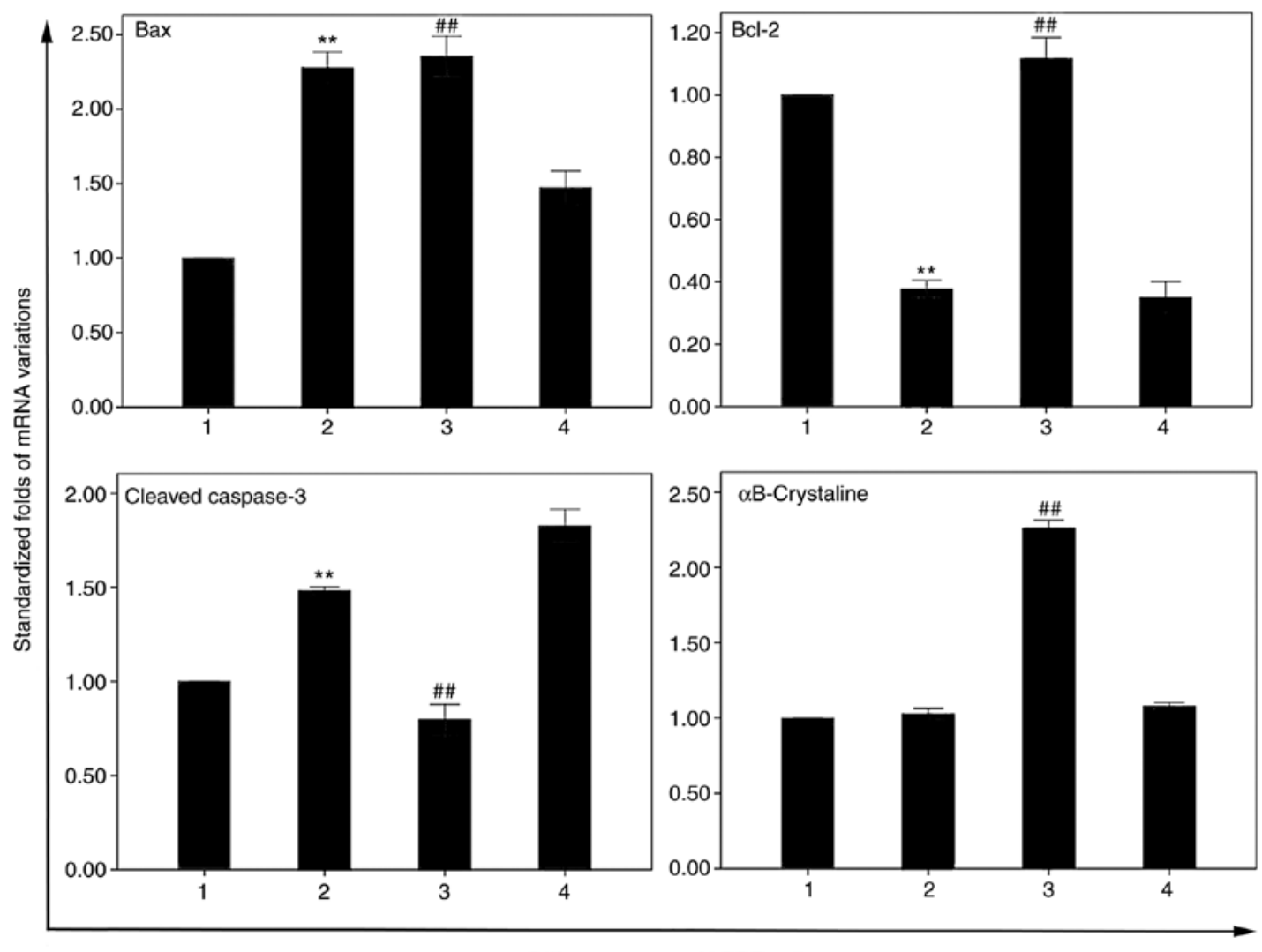

Different groups of $h R P E$ cells

[groups: $1=$ controls, $2=(3 \mathrm{~h}) \mathrm{t}-\mathrm{BH}, 3=(3 \mathrm{~h}) \mathrm{t}-\mathrm{BH}+\mathrm{DHA}, 4=(3 \mathrm{~h}) \mathrm{t}-\mathrm{BH}+\mathrm{DHA}+$ fluoxetine]

Figure 8. RT-PCR demonstrated the variations in Bax, Bcl-2, caspase- 3 and $\alpha B$-crystallin mRNA levels. [Groups: $1=$ control, $2=(3 \mathrm{~h}) \mathrm{t}-\mathrm{BH}, 3=(3 \mathrm{~h}) \mathrm{t}-\mathrm{BH}+\mathrm{DHA}$, $4=(3 \mathrm{~h}) \mathrm{t}-\mathrm{BH}+\mathrm{DHA}+$ fluoxetine]. Following treatment with $300 \mu \mathrm{mol} / \mathrm{l}$ for $3 \mathrm{~h}$, the levels of these mRNAs were tested using RT-PCR. The fold changes in the different groups of human retinal pigment epithelium cells revealed that the oxidative stress enhanced the transcription of Bax and caspase-3, while it reduced that of $\mathrm{Bcl}-2$, and slightly increased that of $\alpha \mathrm{B}$-crystallin. Thus, TREK-TRAAK two-pore domain potassium channels inhibited the oxidation by increasing the transcription of Bax and caspase-3, and decreasing the transcription of Bcl-2, yet further promoting the transcription of $\alpha \mathrm{B}$-crystallin. Data are presented as the mean \pm standard error $(n=3)$ of triplicate experiments. ${ }^{* *} \mathrm{P}<0.01$ vs. control; ${ }^{\# \#} \mathrm{P}<0.01$ vs. $t-B H$ or $D H A+$ fluoxetine groups. t-BH, tert-butyl hydroperoxide; DHA, docosahexaenoic acid; RT-PCR, reverse transcription-polymerase chain reaction.

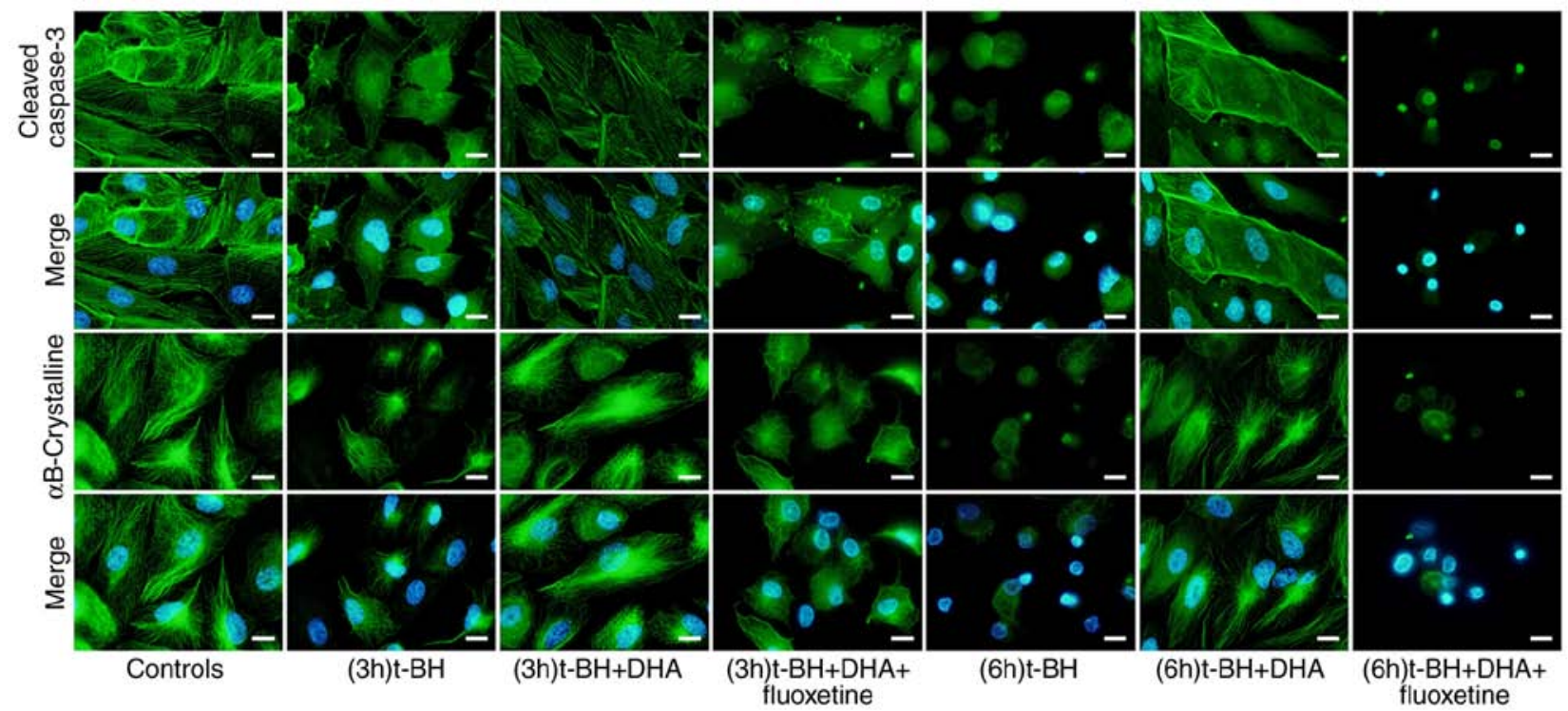

Figure 9. Immunofluorescence analysis demonstrating the variations in the cytoarchitecture of human retinal pigment epithelium cells under oxidative stress. After treatment with $300 \mu \mathrm{mol} / 1 \mathrm{t}-\mathrm{BH}$ for $3 \mathrm{~h}, \mathrm{~F}$-actin and $\alpha$-Tubulin were initially depolymerized, and partially dissolved (white arrows). In the DHA group, this transformation was not observed, while in the fluoxetine co-treatment group, F-actin and $\alpha$-Tubulin were further disintegrated. In cells treated with $300 \mu \mathrm{mol} / 1 \mathrm{t}-\mathrm{BH}$ for $6 \mathrm{~h}$, the natural framework of the cytoskeleton was hardly observed. However, DHA pretreatment maintained the majority of the normal structures, although the frameworks were nebulous in parts. By contrast, the cytoskeleton in the fluoxetine group was worse compared with that in the t-BH group (scale bar, $10 \mu \mathrm{m}$ ). t-BH, tert-butyl hydroperoxide; DHA, docosahexaenoic acid. 


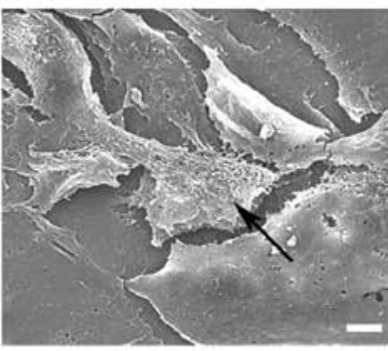

Controls

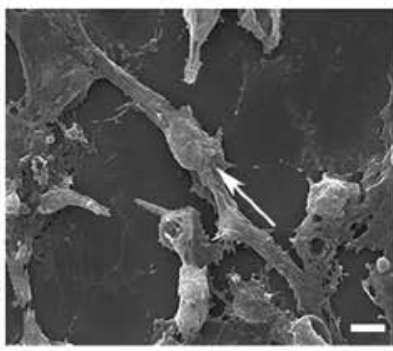

(6h) t-BH

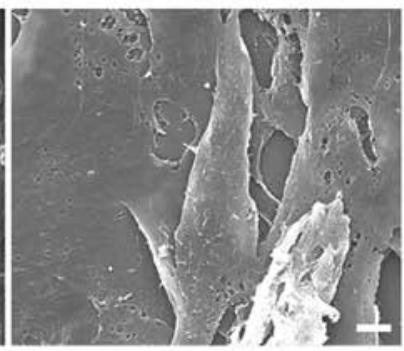

(6h) $\mathrm{t}-\mathrm{BH}+\mathrm{DHA}$

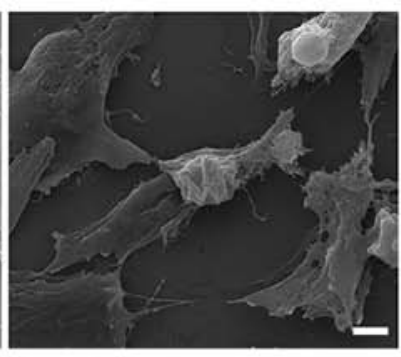

(6h) $\mathrm{t}-\mathrm{BH}+\mathrm{DHA}+$

Figure 10. Scanning electron microscopy demonstrated the extracellular variations in the cytoarchitecture. Treatment with $300 \mu$ mol/l $\mathrm{t}-\mathrm{BH}$ of $6 \mathrm{~h}$ led to atrophy and permeabilization of the cell membrane. Microvilli (black arrows) and pseudopodia were abundant in the control group, however these had mostly vanished in the t-BH group. Cells turned spherical and began to atrophy (white arrow) and abscise. By contrast, the cytoarchitecture of hRPE cells in the DHA group was close to normal. In the fluoxetine co-treatment group, the majority of hRPE cells collapsed as expected (scale bar, $5 \mu \mathrm{m}$ ). hRPE, human retinal pigment epithelium; t-BH, tert-butyl hydroperoxide; DHA, docosahexaenoic acid.

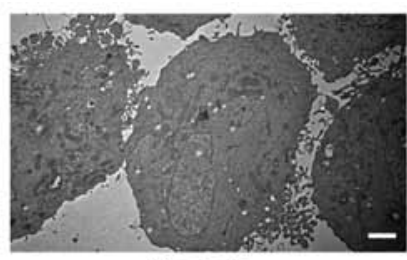

Controls

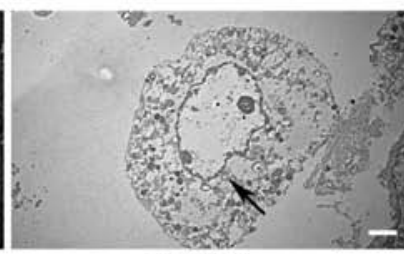

(6h) $\mathrm{t}-\mathrm{BH}$

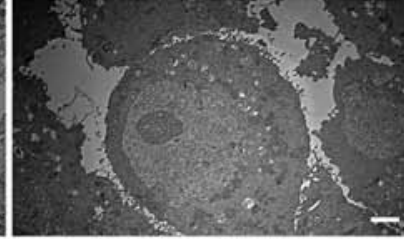

(6h) $\mathrm{t}-\mathrm{BH}+\mathrm{DHA}$

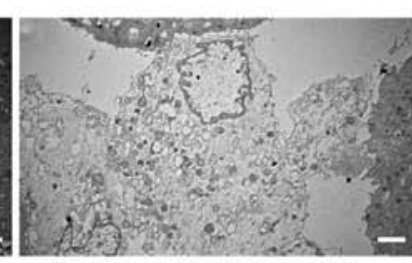

(6h) $\mathrm{t}-\mathrm{BH}+\mathrm{DHA}+$ fluoxetine

Figure 11. Transmission electron microscopy demonstrated the changes inside human retinal pigment epithelium cells. After treatment with $300 \mu$ mol/1 t-BH for $6 \mathrm{~h}$, the majority of normal intracellular structure disappeared: Chromatin condensated, apoptotic bodies were formed (black arrow), cytoplasm dyeing decreased, mitochondrial edema emerged, and endoplasmic reticulum and Golgi bodies were destroyed. Pretreatment with $10 \mu$ mol/1 DHA evidently reduced this collapse, although deformation of nuclei and cytoplasmic organoids were still observed. However, co-treatment with $70 \mu$ mol/1 fluoxetine resulted in severe damage of the intracellular cytoarchitecture (scale bar, $2 \mu \mathrm{m}$ ). t-BH, tert-butyl hydroperoxide; DHA, docosahexaenoic acid.

In conclusion, the present study demonstrated that stimulation of TREK-TRAAK K2P channels enhanced their protective effects on hRPE cells against oxidative stress, which is important in the occurrence and development of retinal degeneration diseases. Thus, these channels may potentially serve as novel targets for future research and therapies for retinal degeneration diseases, such as AMD and RP.

\section{Acknowledgements}

Not applicable.

\section{Funding}

The study was supported in part by the National Natural Science Foundation of China Grants (grant no. 81271012) and the Specialized Research Fund for the Doctoral Program of Higher Education of China (grant no. 20100171120097).

\section{Availability of data and materials}

The datasets analyzed during the current study are available from the corresponding authors on reasonable request.

\section{Authors' contributions}

XZhu designed the experiments. HH, HL, KS, LW and XZhang performed the experiments. The manuscript was written by $\mathrm{HH}$ and all authors read and approved the final manuscript.

\section{Ethics approval and consent to participate}

The present study was approved by the Medical Ethics Committee of Zhongshan Ophthalmic Center, Sun Yat-sen University. Written informed consent was obtained from study participants.

\section{Patient consent for publication}

Study participants provided consent for the publication of their data.

\section{Competing interests}

The authors declare that they have no competing interests.

\section{References}

1. Pascolini D and Mariotti SP: Global estimates of visual impairment: 2010. Br J Ophthalmol 96: 614-618, 2012.

2. Athanasiou D, Aguilà M, Bevilacqua D, Novoselov SS, Parfitt DA and Cheetham ME: The cell stress machinery and retinal degeneration. FEBS Lett 587: 2008-2017, 2013.

3. Zhu XB, Luo Y, Xie L, Gao Y, Ding XY, Ma HJ, Chen HY and Tang SB: Inhibition of photoreceptor apoptosis in RCS rats by caspase-9 inhibitor. Chin J Pathophysiol 23: 7-11, 2007 (In Chinese).

4. Perche O, Doly M and Ranchon-Cole I: Transient protective effect of caspase inhibitors in RCS rat. Exp Eye Res 86: 519-527, 2008.

5. Talley EM, Solorzano G, Lei Q, Kim D and Bayliss DA: Cns distribution of members of the two-pore-domain (KCNK) potassium channel family. J Neurosci 21: 7491-7505, 2001. 
6. Honore E: The neuronal background K2P channels: Focus on TREK1. Nat Rev Neurosci 8: 251-261,2007.

7. Noël J, Sandoz G and Lesage F: Molecular regulations governing TREK and TRAAK channel functions. Channels (Austin) 5: 402-409, 2011.

8. Buckler KJ: Two-pore domain $\mathrm{K}+$ channels and their role in chemoreception. Adv Exp Med Biol 661: 15-30, 2010.

9. Laigle C, Confort-Gouny S, Le Fur Y, Cozzone PJ and Viola A: Deletion of TRAAK potassium channel affects brain metabolism and protects against ischemia. PLoS One 7: e53266, 2012.

10. Bayliss DA and Barrett PQ: Emerging roles for two-pore-domain potassium channels and their potential therapeutic impact. Trends Pharmacol Sci 29: 566-575, 2008.

11. Heurteaux C, Laigle C, Blondeau N, Jarretou G and Lazdunski M: Alpha-linolenic acid and riluzole treatment confer cerebral protection and improve survival after focal brain ischemia. Neuroscience 137 241-251, 2006.

12. Judge SI and Smith PJ: Patents related to therapeutic activation of $\mathrm{K}(\mathrm{ATP})$ and $\mathrm{K}(2 \mathrm{P})$ potassium channels for neuroprotection Ischemic/hypoxic/anoxic injury and general anesthetics. Expert Opin Ther Pat 19: 433-460, 2009.

13. Enyedi P and Czirjak G: Molecular background of leak $\mathrm{K}^{+}$ currents: Two-pore domain potassium channels. Physiol Rev 90 559-605, 2010

14. Querques G, Forte R and Souied EH: Retina and omega-3. J Nutr Metab 2011: 748361, 2011.

15. Kennard LE, Chumbley JR, Ranatunga KM, Armstrong SJ, Veale EL and Mathie A: Inhibition of the human two-pore domain potassium channel, TREK-1, by fluoxetine and its metabolite norfluoxetine. Br J Pharmacol 144: 821-829, 2005

16. Dong YY, Pike AC, Mackenzie A, McClenaghan C, Aryal P, Dong L, Quigley A, Grieben M, Goubin S, Mukhopadhyay S, et al: K2P channel gating mechanisms revealed by structures of TREK-2 and a complex with Prozac. Science 347: 1256-1259, 2015.

17. Lee AK, Smart JL, Rubinstein M, Low MJ and Tse A: Reciprocal regulation of TREK-1 channels by arachidonic acid and CRH in mouse corticotropes. Endocrinology 152: 1901-1910, 2011.

18. Shen C, Li C, Zhu X, Zheng W and Xia R: Effect of TRAAK activator riluzole on t-BHP induced injury of human retinal pigment epithelial cells. Chin J Ocul Fund Dis 29: 400-405, 2013 (In Chinese).

19. Shen CL, Ma W, Zheng W, Huang H, Xia R, Li C and Zhu X: The antioxidant effects of riluzole on the APRE-19 cell model injury-induced by t-BHP. BMC Ophthalmol 17: 210, 2017.

20. Lin SF, Mao YX, Zheng JL, Hu J and Tang SB: An improved primary culture and freezing and recovery method of human retina pigment epithelium. J Pract Med Tech 19: 791-793, 2012 (In Chinese).
21. Livak KJ and Schmittgen TD: Analysis of relative gene expression data using real-time quantitative PCR and the 2(-Delta Delta C(T) method. Methods 25: 402-408, 2001.

22. Plafker SM, O'Mealey GB and Szweda LI: Mechanisms for countering oxidative stress and damage in retinal pigment epithelium. Int Rev Cell Mol Biol 298: 135-177, 2012.

23. Wei MC, Zong WX, Cheng EH, Lindsten T, Panoutsakopoulou V, Ross AJ, Roth KA, MacGregor GR, Thompson CB and Korsmeyer SJ: Proapoptotic BAX and BAK: A requisite gateway to mitochondrial dysfunction and death. Science 292: 727-730, 2001.

24. Shi Y: Mechanisms of caspase activation and inhibition during apoptosis. Mol Cell 9: 459-470, 2002.

25. Sheekumar PG, Chothe P, Sharma KK, Baid R, Kompella U, Spee C, Kannan N, Manh C, Ryan SJ, Ganapathy V, et al: Antiapoptotic properties of alpha-crystallin-derived peptide chaperones and characterization of their uptake transporters in human RPE cells. Invest Ophthalmol Vis Sci 54: 2787-2798, 2013.

26. Ousman SS, Tomooka BH, van Noort JM, Wawrousek EF, O'Connor KC, Hafler DA, Sobel RA, Robinson WH and Steinman L: Protective and therapeutic role for alphaB-crystallin in autoimmune demyelination. Nature 448: 474-479, 2007.

27. CorrochanoS, Barhoum R,BoyaP,Arroba AI, Rodríguez-MuelaN, Gómez-Vicente V, Bosch $F$, de Pablo $F$, de la Villa $P$ and de la Rosa EJ: Attenuation of vision loss and delay in apoptosis of photoreceptors induced by proinsulin in a mouse model of retinitis pigmentosa. Invest Ophthalmol Vis Sci 49: 4188-4194, 2008.

28. Heisenberg CP and Bellaïche Y: Forces in tissue morphogenesis and patterning. Cell 153: 948-962, 2013.

29. Blanchoin L, Boujemaa-Paterski R, Sykes C and Plastino J: Actin dynamics, architecture, and mechanics in cell motility. Physiol Rev 94: 235-263, 2014.

30. Dan Dunn J, Alvarez LA, Zhang X and Soldati T: Reactive oxygen species and mitochondria: A nexus of cellular homeostasis. Redox Biol 6: 472-485, 2015.

This work is licensed under a Creative Commons Attribution-NonCommercial-NoDerivatives 4.0 International (CC BY-NC-ND 4.0) License. 